\title{
Comparison of warm fluid and cold fluid resuscitation during uncontrolled hemorrhagic shock model in rats
}

\author{
Serkan Dilmen, M.D., ${ }^{1}$ Mehmet Eryılmaz, M.D., ${ }^{2}$ Salih Müjdat Balkan, M.D., ${ }^{3}$ Muhittin Serdar, M.D., ${ }^{4}$ \\ Murat Durusu, M.D., ${ }^{2}$ Ali Osman Yıldırım, M.D., ${ }^{5}$ Sanem Aslıhan Dilmen, M.D. ${ }^{6}$
}

\author{
${ }^{1}$ Department of Cardiovascular Surgery, Gülhane Military Medical Academy, Ankara-Turkey \\ 2Department of Emergency Medicine, Gülhane Military Medical Academy, Ankara-Turkey \\ ${ }^{3}$ Department of General Surgery, TOBB ETU Hospital, Ankara-Turkey \\ ${ }^{4}$ Department of Biochemistry, Acıbadem University Faculty of Medicine, Ankara-Turkey \\ ${ }^{5}$ Department of Emergency Medicine, GATA Haydarpaşa Military Hospital, İstanbul-Turkey \\ ${ }^{6}$ Department of Physical Medicine and Rehabilitation, Ankara Physical Medicine and Rehabilitation Training and Research Hospital, Ankara-Turkey
}

\begin{abstract}
BACKGROUND: This study was designed to compare the effects of resuscitation with cold and warm fluid on survival time, rate and volume of hemorrhage, hemodynamics, hypothermia, coagulopathy, acid-base balance, hematocrit, lactate, and base deficit during uncontrolled hemorrhagic shock (HS) model in rats.

METHODS: HS model was created with splenic vascular and parenchymal injury in 29 rats under ketamine and xylazine anesthesia. Thirty minutes after the hemorrhage, the rats were randomized to receive $14.5 \mathrm{~mL} / \mathrm{kg} 0.9 \%$ sodium chloride solution at either $24^{\circ} \mathrm{C}$ (Group I; n=9) or $4^{\circ} \mathrm{C}$ (Group 2; n= I0) for 20 minutes. Groups I and 2 were compared with group that did not receive fluid (Group 3; $n=10$ ). Statistical data were represented as mean \pm SD. SPSS for Windows, Version 15.0 (SPSS, Inc., Chicago, IL, USA) software, Bonferroni-adjusted Mann-Whitney $U$ test and Kaplan-Meier procedure were used to perform statistical data analysis. $P$ value of $\leq 0.05$ was considered statistically significant.
\end{abstract}

RESULTS: Cold fluid resuscitation decreased survival time due to increased rate and volume of hemorrhage, acidosis, hypothermia, lactate, and base deficit and decreased blood pressure and hematocrit.

CONCLUSION: There is a great need for further experimental and clinical trials on fluid resuscitation in trauma in order to define which fluid should be administered, temperature of the fluid, quantity to be delivered, and duration.

Keywords: Fluid resuscitation; hemorrhagic shock; intravenous cold fluid; rat.

\section{INTRODUCTION}

The most common cause of death under the age of 40 years is trauma. ${ }^{[1]}$ The most frequent cause of early death due to trauma is bleeding and shock. ${ }^{[2]}$ In developed and developing countries, $50 \%$ to $80 \%$ of deaths due to trauma occur in the prehospital field. ${ }^{[3]}$ Recent studies investigating means to

Address for correspondence: Serkan Dilmen, M.D.

Gülhane Askeri Tıp Akademisi, Kalp ve Damar Cerrahisi

Anabilim Dalı, Keçiören, 00160 Ankara, Turkey

Tel: +90 312 - 3042000 E-mail: drserkandilmen@hotmail.com

Submitted: 17.02.2016

Ulus Travma Acil Cerrahi Derg

Accepted: 08.11 .2016

2017;23(4):287-293

doi: $10.5505 /$ tjtes. 2016.50487

Copyright 2017

TJTES reduce mortality related to trauma have targeted the prehospital field, and have focused on fluid resuscitation as a way to reduce prehospital mortality. ${ }^{[4,5]}$ The temperature of the fluid used in such resuscitation is a new area of discussion. There are numerous studies about hypothermic fluid resuscitation in non-trauma patients. This type of fluid resuscitation is included in the guidelines for management of non-trauma related cardiac arrest, but there are no clinical studies about the use of this treatment in trauma patients. Available limited experimental studies are inconclusive. In this study, it was hypothesized that cold fluid resuscitation, which has had beneficial effects in cardiac arrest patients, would also prolong survival in trauma.

\section{MATERIALS AND METHODS}

The study protocol was approved by the Gülhane Military Medical Academy animal experimentation ethics commit- 
tee, on April I, 20II (file number II/I0). The study subjects were 30 male Sprague Dawley rats weighing between 217 and $376 \mathrm{~g}$. The animals were fed commercial rat chow and provided with tap water until surgery. They were kept in cages at room temperature for more than I week. All of the animals were sedated with intraperitoneal injection of $x y-$ lazine $(4 \mathrm{mg} / \mathrm{kg})$ and ketamine $(40 \mathrm{mg} / \mathrm{kg})$; additional doses were administered if necessary. One animal died and was excluded from the study. After sedation, the animals were placed in supine position for spontaneous breathing. After the tail was heated with an external heater to between $45^{\circ} \mathrm{C}$ and $50^{\circ} \mathrm{C}$ for I minute, the tail artery was cannulated with 26-gauge intracath (Mediflon; Eastern Medikit Ltd., Gurgaon, India) for hemodynamic monitoring and blood sampling, and the lateral tail vein was cannulated with 26-gauge intracath (Mediflon; Eastern Medikit Ltd., Gurgaon, India) for fluid resuscitation (Figure I). Cardiocap/5 monitor (Model F-FML;

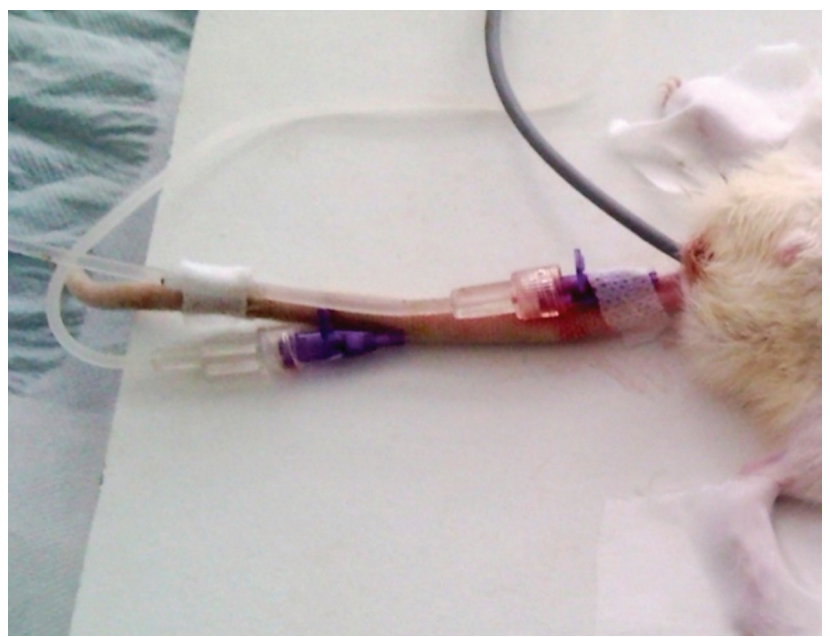

Figure 1. Tail artery and lateral vein cannulation. Cardiocap/5 monitor and temperature probe (Model F-FML; Datex-Ohmeda, Inc., GE Healthcare Finland Oy, Helsinki, Finland).

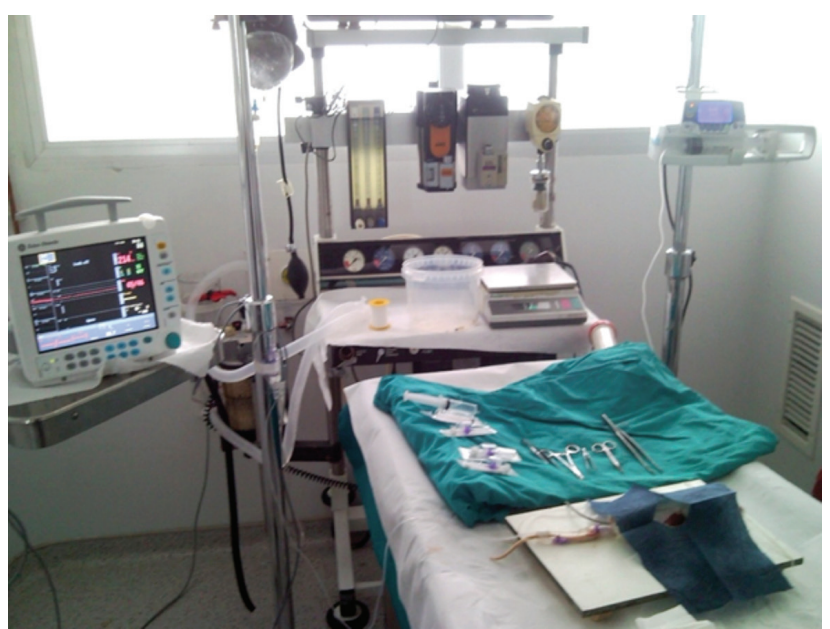

Figure 2. Hemodynamic and rectal temperature monitoring with Cardicap/5 monitor (Model F-FML; Datex-Ohmeda, Inc., GE Healthcare Finland Oy, Helsinki, Finland). Fluid resuscitation with infusion pump (Injectomat Agilia; Fresenius Kabi, Brezins, France).
Datex-Ohmeda, Inc., GE Healthcare Finland Oy, Helsinki, Finland) with temperature probe, and pressure monitor set (Zyron, Point Medikal San. Ve Tic. Ltd. Şti., Ankara, Turkey) were used for hemodynamic and rectal temperature (RT) monitoring (Figures I, 2). Preparations were completed within 45 minutes, and the rats were allowed 10 minutes to become stable. Mean arterial blood pressure (MAP), heart rate $(H R), R T$, arterial blood gas (ABG) parameters [pH, hematocrit (HCT), lactate, base deficit], and D-dimer levels were recorded before hemorrhage was initiated. Stat Profile Critical Care Xpress blood gas analyzer (Nova Biomedical, Inc., Waltham, MA, USA) and Amax CS-190 coagulation analyzer (Trinity Biotec, Lemgo, Germany) were used for these measurements. Blood samples $(0.5 \mathrm{~mL})$ were collected from tail artery at 0 minute (before starting hemorrhage), 60 minutes, and every 30 minutes subsequently using heparinized syringe (BD Preset Eclipse, Belliver Industrial Estate, Plymouth, UK). After blood samples were collected, intravenous (IV) saline solution $(0.5 \mathrm{~mL})$ was infused in 3 minutes to replace these samples. Five minutes after recording the data, the abdominal wall of the rat was sterilized, and the abdomen was entered via a left subcostal incision. Splenic parenchymal incision was made in transverse direction at I level, and I of the 3 main branches of the splenic artery was cut (Figure 3). After allowing free flow of blood into the peritoneal cavity, abdominal incision was sutured. Thirty minutes after hemorrhage, rats were randomized to receive either $24^{\circ} \mathrm{C}$ (Group I; $n=9$ ) or $4^{\circ} \mathrm{C}$ (Group 2; $\mathrm{n}=10$ ) $0.9 \%$ sodium chloride solution (14.5 $\mathrm{mL} / \mathrm{kg}$ ) via infusion pump (Injectomat Agilia; Fresenius Kabi, Brezins, France) for 20 minutes (Figure 2). Quantity of fluid was chosen to simulate I liter of fluid for $70 \mathrm{~kg}$ patient since healthcare personnel can carry and administer I liter of fluid easily to a bleeding patient in the field. Twenty minutes was selected to simulate the time for transportation of patient from the field to the hospital. Groups I and 2 were compared with the control group, which did not receive fluid treatment

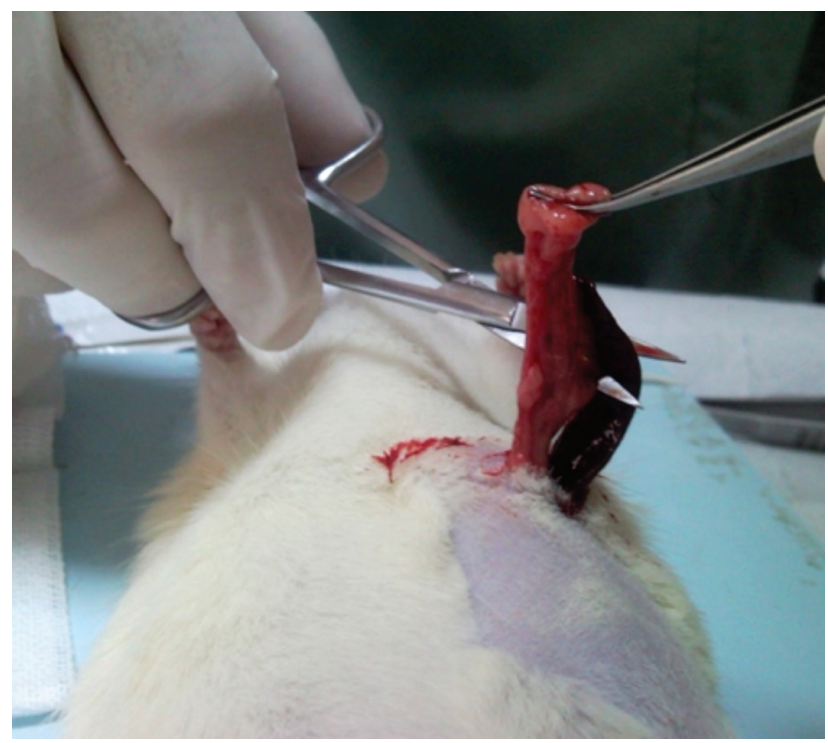

Figure 3. Splenic parenchymal incision. 
(Group 3; $n=10)$. The rats were observed at room temperature without any other treatment. Apnea and lack of pulse were defined as signs of death. Once death occurred, the peritoneal cavity was opened immediately, and the volume of hemorrhage was measured on a scale (Precisa Gravimetrics A.G., Dietikon, Switzerland) by calculating the difference in weight between dry gauze and gauze soaked with blood clots. MAP, HR, and RT were evaluated at 0, 30, 40, 60 minutes, and subsequently every 30 minutes until the animal died. Afterward, volume and rate of hemorrhage, and survival time were recorded. Volume of hemorrhage was calculated as percentage of total blood volume $(60 \mathrm{~mL} / \mathrm{kg})$. Rate of hemorrhage was calculated as $\mathrm{mL} / \mathrm{kg} / \mathrm{h}$.

SPSS for Windows, Version I5.0 (SPSS, Inc., Chicago, IL, USA) was used to perform statistical analysis. Statistical data are presented as mean $\pm S D$. Differences between groups were analyzed using Bonferroni-adjusted Mann-Whitney $U$ test. Differences between groups in terms of survival time were assessed using Kaplan-Meier survival analysis. In determining the number of subjects in each group, effect size of I.52 was estimated based on a previous study (2). Sample size of 8 subjects in each group would allow us to detect statistically significant difference with 5\% Type I error risk and $80 \%$ power. $P$ value of $\leq 0.05$ was considered statistically significant.

\section{RESULTS}

There were no statistically significant differences between groups in terms of weight of rats, MAP, HR, RT, ABG parameters, or D-dimer level at the beginning of the experiment (Table I). There were statistically significant differences between groups in survival time and volume and rate of hemorrhage (Table 2) (Figure 4).

\section{Hemodynamic Changes}

Thirty minutes after hemorrhage, MAP, HR, and RT decreased without significant difference in all groups. Final analysis revealed that Group 3 had significantly lower MAP and HR than Groups I and $2(p<0.05)$. Group I had significantly higher MAP than Group 2 ( $p<0.05)$. There were no significant differences between Groups I and 2 in terms of HR. Group 3 had sig-

Table I. Weight of rats, MAP, HR, RT, ABG parameters, and D-dimer level in the groups at the beginning of the experiment

\begin{tabular}{|c|c|c|c|c|c|c|c|c|c|}
\hline & \multicolumn{2}{|r|}{ Group I } & \multicolumn{2}{|r|}{ Group 2} & \multicolumn{2}{|r|}{ Group 3} & \multirow{2}{*}{$\begin{array}{c}\text { PI } \\
\text { Groups } \\
\text { I and } 2\end{array}$} & \multirow{2}{*}{$\begin{array}{c}\text { P2 } \\
\text { Groups } \\
\text { I and } 3\end{array}$} & \multirow{2}{*}{$\begin{array}{c}\text { P3 } \\
\text { Groups } \\
2 \text { and } 3\end{array}$} \\
\hline & $\mathbf{n}$ & Mean士SD & $\mathbf{n}$ & Mean士SD & $\mathbf{n}$ & Mean士SD & & & \\
\hline Weight (g) & 9 & $279.56 \pm 33.52$ & 10 & $280.26 \pm 36.45$ & 10 & $273.20 \pm 35.40$ & 0.604 & 0.780 & 0.579 \\
\hline MAP (mmHg) & 9 & $97.00 \pm 5.17$ & 10 & $98.00 \pm 12.11$ & 10 & $96.70 \pm 5.89$ & 0.549 & 0.905 & 0.739 \\
\hline HR (beats/min) & 9 & $343.67 \pm 48.89$ & 10 & $365.08 \pm 35.15$ & 10 & $340.65 \pm 49.74$ & 0.243 & 0.968 & 0.393 \\
\hline $\mathrm{RT}\left({ }^{\circ} \mathrm{C}\right)$ & 9 & $37.18 \pm 0.20$ & 10 & $37.01 \pm 0.07$ & 10 & $37.07 \pm 0.14$ & 0.065 & 0.278 & 0.436 \\
\hline Base deficit (mEq/L) & 9 & $-1.44 \pm 0.65$ & 10 & $-1.00 \pm 1.04$ & 10 & $-1.65 \pm 1.14$ & 0.278 & 0.497 & 0.247 \\
\hline D-dimer (ng/mL) & 9 & $141.78 \pm 10.93$ & 10 & $|4| .80 \pm 28.05$ & 10 & $14 \mid .65 \pm 34.79$ & 0.720 & 0.842 & 1.000 \\
\hline $\mathrm{pH}$ & 9 & $7.4 I \pm 0.03$ & 10 & $7.40 \pm 0.02$ & 10 & $7.40 \pm 0.02$ & 0.842 & 0.661 & 0.853 \\
\hline HCT (\%) & 9 & $50.56 \pm 2.07$ & 10 & $50.70 \pm 2.91$ & 10 & $50.55 \pm 1.89$ & 0.603 & 0.564 & 0.684 \\
\hline Lactate (mmol/L) & 9 & $1.77 \pm 0.52$ & 10 & $1.85 \pm 0.38$ & 10 & $1.86 \pm 0.36$ & 0.661 & 0.497 & 0.971 \\
\hline
\end{tabular}

Group I: Warm fluid therapy. Group 2: Cold fluid therapy. Group 3: Control.

MAP: Mean arterial blood pressure; HR: Heart rate; RT: Rectal temperature; ABG: Arterial blood gas; HCT: Hematocrit; SD: Standard deviation.

Table 2. Survival time, volume of hemorrhage, and rate of hemorrhage in the groups

\begin{tabular}{|c|c|c|c|c|c|c|c|c|c|}
\hline & \multicolumn{2}{|r|}{ Group I } & \multicolumn{2}{|r|}{ Group 2} & \multicolumn{2}{|c|}{ Group 3} & \multirow{2}{*}{ 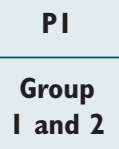 } & \multirow{2}{*}{ 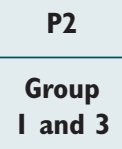 } & \multirow{2}{*}{$\begin{array}{c}\text { P3 } \\
\text { Groups } \\
2 \text { and } 3\end{array}$} \\
\hline & $\mathbf{n}$ & Mean $\pm S D$ & $\mathbf{n}$ & Mean $\pm S D$ & $\mathbf{n}$ & Mean $\pm S D$ & & & \\
\hline Survival time (min) & 9 & $268.00 \pm 50.71$ & 10 & $215.92 \pm 54.37$ & 10 & $75.70 \pm 16.55$ & 0.042 & $<0.001$ & $<0.001$ \\
\hline \multicolumn{10}{|l|}{ Volume of } \\
\hline Hemorrhage (\%) & 9 & $24.37 \pm 8.43$ & 10 & $36.5 I \pm 8.47$ & 10 & $52.29 \pm 12.30$ & 0.003 & 0.001 & 0.011 \\
\hline \multicolumn{10}{|l|}{ Rate of hemorrhage } \\
\hline$(\mathrm{mL} / \mathrm{kg} / \mathrm{h})$ & 9 & $3.50 \pm 1.45$ & 10 & $6.58 \pm 3.23$ & 10 & $27.49 \pm 11.29$ & 0.010 & $<0.001$ & $<0.001$ \\
\hline
\end{tabular}

Group I: Warm fluid therapy. Group 2: Cold fluid therapy. Group 3: Control. SD: Standard deviation. 
Table 3. Comparison of the groups in terms of MAP, HR, RT, HCT, and D-dimer at timed intervals after hemorrhagic shock

\begin{tabular}{|c|c|c|c|c|c|}
\hline \multirow[t]{2}{*}{ Parameters } & \multicolumn{4}{|c|}{ Comparison of fluid therapies between groups } & \\
\hline & Warm $^{*}>$ Cold $^{+}$ & Warm $>$Control $^{\circ}$ & Cold $>$ Control & Cold $<$ Control & \\
\hline MAP & 180 & $40,50,60,90$ & $40,50,60,90$ & - & $\begin{array}{c}\text { Time (minute) after } \\
\text { HS with } p<0.05\end{array}$ \\
\hline HR & No difference & 90 & 50,90 & - & \\
\hline RT & $\begin{array}{c}40,50,60,90,120 \\
150,180,210\end{array}$ & No difference & - & $40,50,60,90$ & \\
\hline $\mathrm{HCT}$ & 90,120 & 60,90 & 60,90 & - & \\
\hline D-dimer & No difference & No difference & No difference & - & \\
\hline
\end{tabular}

nificantly higher RT than Group 2 ( $p<0.05)$. Group 3 also had lower RT than Group I without significant difference. Group I had significantly higher RT than Group $2(p<0.05)$ (Table 3).

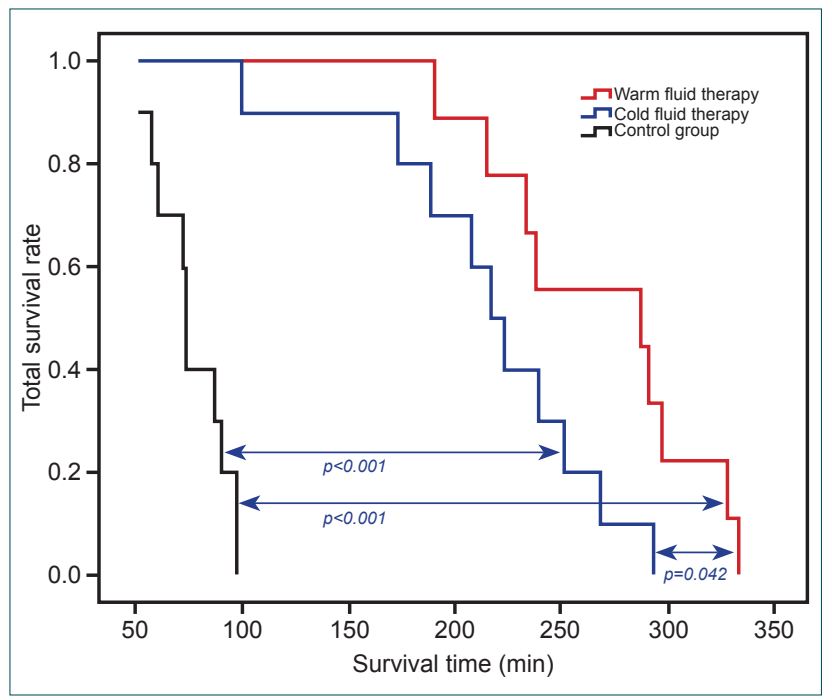

Figure 4. Cumulative survival (Kaplan-Meier) during hemorrhagic shock.

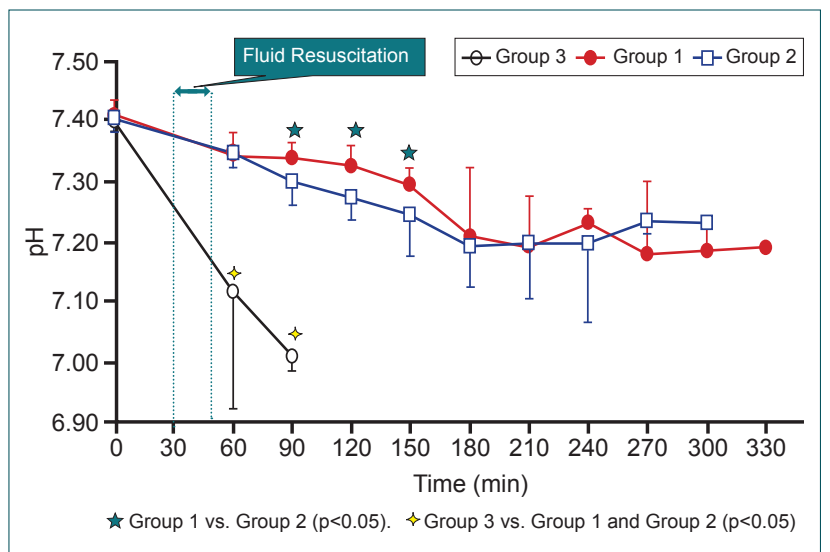

Figure 5. PH level during hemorrhagic shock. Group 1: Warm fluid therapy. Group 2: Cold fluid therapy. Group 3: Control.

\section{ABG Parameters}

During the study, base deficit/lactate levels increased, and $\mathrm{pH} /$ HCT levels decreased in all groups. Group 3 had significantly higher base deficit/lactate level and lower $\mathrm{pH} / \mathrm{HCT}$ level than Groups I and 2 (Table 3 and Figures 5-7). Group 2 had significantly higher base deficit/lactate level and lower $\mathrm{pH} / \mathrm{HCT}$

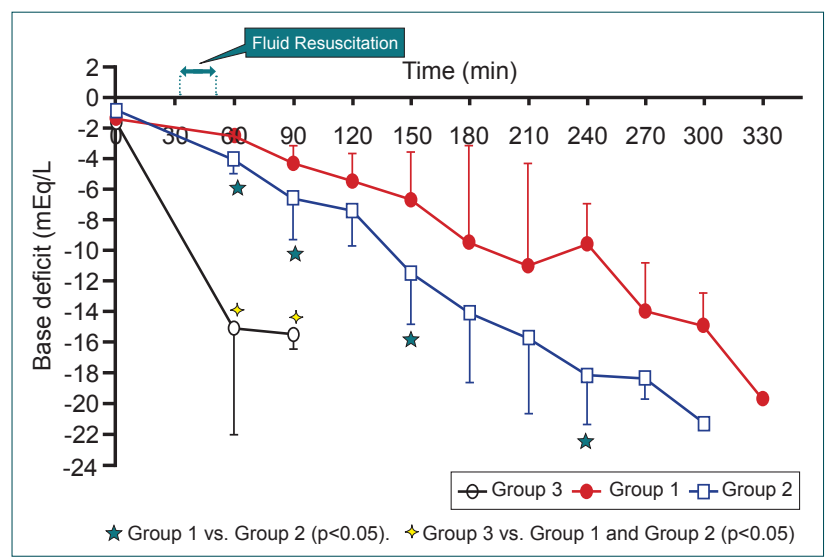

Figure 6. Base deficit level during hemorrhagic shock. Group 1: Warm fluid therapy. Group 2: Cold fluid therapy. Group 3: Control.

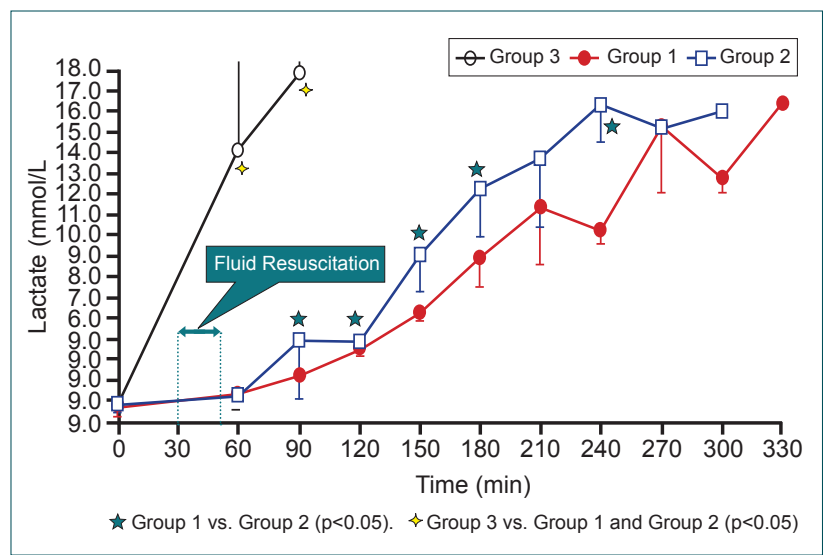

Figure 7. Lactate level during hemorrhagic shock. Group 1: Warm fluid therapy. Group 2: Cold fluid therapy. Group 3: Control. 
level than Group I (Table 3 and Figures 5-7).

D-dimer: No statistically significant difference was determined between groups in D-dimer level (Table 3).

\section{DISCUSSION}

The primary finding of the present study was that warm fluid resuscitation had more beneficial effects on survival than cold fluid resuscitation. Many clinical and experimental studies focusing on prehospital cardiac arrest have demonstrated that cold fluid resuscitation positively contributes to survival time, hemodynamics, acid-base balance, and neurological and renal functions. ${ }^{[6-9]}$ Conversely, we observed deleterious effects of this treatment in trauma-related hemorrhagic shock (HS). In the literature, there are only 2 studies that compare fluid resuscitation at different temperatures in HS model, and both of these were pig models. ${ }^{[2,10]}$ Our study is the first to be conducted using rats. Norio et al. ${ }^{[2]}$ reported that cold fluid infusion increased survival time. They thought this was a result of therapeutic hypothermia, which decreased HR and stroke volume index, and thus reduced oxygen demand of the heart. ${ }^{[2]}$ In contrast, we found that cold fluid infusion decreased survival time. Cold fluid infusion may have increased volume and rate of hemorrhage, hypothermia, and acidosis, which might be related to poor tissue perfusion by causing vasoconstriction. As we did, Wu et al. ${ }^{[10]}$ found that cold fluid infusion decreased survival time compared with warm fluid infusion, but they also detected that $2{ }^{\circ} \mathrm{C}$ and $24^{\circ} \mathrm{C}$ fluid infusions increased survival time compared with $38^{\circ} \mathrm{C}$ fluid infusion due to therapeutic hypothermia $\left(34^{\circ} \mathrm{C}\right) .^{[10]}$ In our study, increasing volume and rate of hemorrhage in cold fluid infusion group might be due to hypothermic coagulopathy. This coagulopathy might be explained by hypothermia below $34^{\circ} \mathrm{C}$, which results in platelet dysfunction, inhibition of protein kinase $D$, and increased prostacyclin synthesis. ${ }^{[2,1]]}$ Norio et al. ${ }^{[2]}$ did not find significant differences between groups in terms of volume of hemorrhage. They attributed this finding to stable body temperature of $35.5^{\circ} \mathrm{C}$ in cold fluid infusion group, and thus, did not encounter any hypothermic coagulopathy. While Norio et al. and Wu et al. ${ }^{[2,10]}$ didn't indicate significant differences between groups in terms of MAP, we found that cold fluid infusion decreased MAP. Cold fluid infusion may have increased hypothermia and acidosis, and thus decreased MAP due to cardiac arrhythmia and low cardiac output. While these studies determined lower HR in cold fluid infusion groups, we didn't find a significant difference between treatment groups in terms of HR. They considered low HR to be result of protective effect of hypothermia on heart. ${ }^{[2,10]}$ Unlike those studies, we observed that HR after treatment didn't remain at stable level, and always fell. This result can be explained by HR decreases in rats based on parasympathetic activation, instead of sympathetic activation in the heart, when blood pressure falls. $[12,13]$ Norio et al. ${ }^{[2]}$ found cold fluid infusion increased $\mathrm{HCT}$, and attributed this finding to hypothermia-induced hemoconcentration generated by plasma leakage into extravascular spaces. We observed that cold fluid infusion decreased HCT. We think this finding may have been due to greater volume and rate of hemorrhage in cold fluid infusion group. While Norio and $\mathrm{Wu}$ et al. ${ }^{[2,10]}$ didn't report significant differences between groups in terms of $\mathrm{pH}$ and base deficit, we found that cold fluid infusion decreased $\mathrm{pH}$ and increased lactate and base deficit levels as result of acidosis. As in our study, Wu et al. ${ }^{[10]}$ found that cold fluid infusion increased lactate levels with acidosis. However, there was no correlation between lactate and base deficit levels in their study. Normally, base deficit increases when lactate increases. After treatment of HS, lactate and base deficit are expected to decrease. ${ }^{[14]}$ Conversely, the previous authors indicated base deficit and lactate levels increased after treatment. There were also other differences in materials and methods used in our study in comparison with these 2 studies. They included volume-controlled hemorrhagic stage, which did not totally represent an uncontrolled HS model, and thus did not simulate trauma very well. ${ }^{[15,16]}$ These studies simulated hospital phase more than prehospital phase, as they incorporated mechanical ventilation and intensive care. We excluded this stage to simulate prehospital phase for trauma patients. There was also no control group in those studies. Furthermore, coagulopathy, one of the parameters of the "lethal triad" in HS, was not evaluated. ${ }^{[2,10]}$ In a previous study conducted by Zhang et al.,, ${ }^{[17]}$ it was reported that $\mathrm{D}$-dimer might be prognostic factor in a rat model of HS. We used D-dimer, a fibrin degradation product, to assess coagulopathy; however, there was no significant difference in D-dimer level between groups. We think D-dimer may not be a suitable parameter for evaluation coagulopathy since there are some differences between humans and rats in terms of coagulation system. ${ }^{[18]}$ We believe that further studies are required to demonstrate relationship between $\mathrm{D}$-dimer and coagulopathy during HS.

In addition to our main findings, interestingly, we found that compared with the control group, both treatment groups had smaller volume and lower rate of hemorrhage, and thus had higher MAP, HR, HCT, and $\mathrm{pH}$, as well as lower lactate and base deficit. This result could be explained by the fact that infusions were colder than body temperature and therefore caused vasoconstriction, and/or volume of fluid used in resuscitation was less than has been used in other studies. ${ }^{[19-23]}$ Other studies found aggressive fluid therapy at dose of 35$70 \mathrm{~mL} / \mathrm{kg}$ increased volume and rate of hemorrhage because it caused dilutional coagulopathy, hypothermia, disruption of thrombus formation, higher blood pressure, and inhibition of vasoconstriction. ${ }^{[19-23]}$ Low dose $(14.5 \mathrm{~mL} / \mathrm{kg})$ of fluid may decrease volume and rate of hemorrhage. As a result, we think that crystalloid fluid resuscitation at dose of $14.5 \mathrm{~mL} / \mathrm{kg}$ for 20 minutes, even at different temperatures, can have beneficial effects on survival.

\section{Limitations}

The limitations of the present study are lack of large animal 
model and of hot fluid resuscitation group. We may not have simulated real clinical situations using small animal model. For example, rats are more prone to hypothermia than pigs. We observed deep hypothermia $\left(25^{\circ} \mathrm{C}\right)$ instead of therapeutic hypothermia $\left(34^{\circ} \mathrm{C}\right)$ during the experiment. Anesthetic agents, fluids that were colder than body temperature, exposure to room temperature, HS, and laparotomy might have also triggered deep hypothermia in rats. In theory, HS patients should receive fluid resuscitation at body temperature to prevent hypothermia. ${ }^{[24]}$ If we could have added $37^{\circ} \mathrm{C}$ hot fluid infusion group to our study, we would have been able to better compare efficiency of fluid therapies at different temperature.

\section{Conclusion}

Cold fluid resuscitation decreased survival time because it increased rate and volume hemorrhage, acidosis, and hypothermia. During pre-hospital phase (the time before patient arrival to hospital), also known as the "golden hour," fluid resuscitation should be administered immediately in order to decrease mortality. Additional experimental studies, especially including large animal models and clinical studies, are needed to further examine fluid resuscitation, including temperature and type of fluid, quantity of fluid to be provided, and duration of administration by evaluating effects on acidosis, coagulopathy, and hypothermia.

\section{Conflict of interest: None declared.}

\section{REFERENCES}

1. Faist E, Baue AE, Dittmer H, Heberer G. Multiple organ failure in polytrauma patients. Journal of Trauma 1983;23:775-8. [CrossRef]

2. Norio H, Takasu A, Kawakami M, Saitoh D, Sakamoto T, Okada Y. Rapid body cooling by cold fluid infusion prolongs survival time during uncontrolled hemorrhagic shock in pigs. J Trauma 2002;52:1056-61.

3. Ertekin C. Approach to the patient with multiple trauma. Turkish Journal of Intensive Care Medicine 2002;2(2):77-87.

4. Bilkovski RN, Rivers EP, Horst HM. Targeted resuscitation strategies after injury. Curr Opin Crit Care 2004;10:529-38. [CrossRef]

5. Mapstone J, Roberts I, Evans P. Fluid resuscitation strategies: a systematic review of animal trials. J Trauma 2003;55:571-89. [CrossRef]

6. Kliegel A, Losert H, Sterz F, Kliegel M, Holzer M, Uray T, et al. Cold simple intravenous infusions preceding special endovascular cooling for faster induction of mild hypothermia after cardiac arrest--a feasibility study. Resuscitation 2005;64:347-51. [CrossRef]

7. Kämäräinen A, Virkkunen I, Tenhunen J, Yli-Hankala A, Silfvast T. Induction of therapeutic hypothermia during prehospital CPR using icecold intravenous fluid. Resuscitation 2008;79:205-11. [CrossRef]

8. Polderman KH, Rijnsburger ER, Peerdeman SM, Girbes AR. Induc- tion of hypothermia in patients with various types of neurologic injury with use of large volumes of ice-cold intravenous fluid. Crit Care Med 2005;33:2744-51. [CrossRef]

9. Bernard S, Buist M, Monteiro O, Smith K. Induced hypothermia using large volume, ice-cold intravenous fluid in comatose survivors of out-ofhospital cardiac arrest: a preliminary report. Resuscitation 2003;56:913. [CrossRef]

10. Wu X, Kochanek PM, Cochran K, Nozari A, Henchir J, Stezoski SW, et al. Mild hypothermia improves survival after prolonged, traumatic hemorrhagic shock in pigs. J Trauma 2005;59:291-301. [CrossRef]

11. Dogan Z. Retrospective Analysis of the pediatric patients with trauma presenting to emergency service. Emergency medicine specialty thesis. Cumhuriyet University Medical Faculty Emergency Department, Sivas 2008.

12. Little RA. 1988 Fitts lecture: heart rate changes after haemorrhage and injury--a reappraisal. J Trauma 1989;29:903-6. [CrossRef]

13. Secher NH, Sander Jensen K, Werner C, Warberg J, Bie P. Bradycardia during severe but reversible hypovolemic shock in man. Circ Shock 1984;14:267-74.

14. Kline JA. Shock. In: Marx JA, editor. Rosens's Emergency Medicine Concepts and Clinical Practice. 7th ed. Mosby: St Louis; 2010, p. 34-41.

15. Durusu M, Eryilmaz M, Oztürk G, Menteş O, Ozer T, Deniz T. Comparison of permissive hypotensive resuscitation, low-volume fluid resuscitation, and aggressive fluid resuscitation therapy approaches in an experimental uncontrolled hemorrhagic shock model. Ulus Travma Acil Cerrahi Derg 2010;16:191-7.

16. Lomas-Niera JL, Perl M, Chung CS, Ayala A. Shock and Hemorrhage: An Overview of Animal Models. Shock 2005;24:33-9. [CrossRef]

17. Zhang YJ, Pan JY, Wang MS. Study on changes of blood coagulation factors in rats with hemorrhagic shock. Zhongguo Shi Yan Xue Ye Xue Za Zhi 2005;13:110-3.

18. Prueckner S, Safar P, Kentner R, Stezoski J, Tisherman SA. Mild hypothermia increases survival from severe pressure-controlled hemorrhagic shock in rats. J Trauma 2001;50:253-62. [CrossRef]

19. Solomonov E, Hirsh M, Yahiya A, Krausz MM. The effect of vigorous fluid resuscitation in uncontrolled hemorrhagic shock after massive splenic injury. Crit Care Med 2000;28:749-54. [CrossRef]

20. Hatoum OA, Bashenko Y, Hirsh M, Krausz MM. Continuous fluid resuscitation for treatment of uncontrolled hemorrhagic shock following massive splenic injury in rats. Shock 2002;18:574-9. [CrossRef]

21. Krausz MM, Bashenko Y, Hirsh M. Crystalloid or colloid resuscitation of uncontrolled hemorrhagic shock after moderate splenic injury. Shock 2000;13:230-5. [CrossRef]

22. Krausz MM, Bashenko Y, Hirsh M. Crystalloid and colloid resuscitation of uncontrolled hemorrhagic shock following massive splenic injury. Shock 2001;16:383-8. [CrossRef]

23. Bickell WH, Wall MJ Jr, Pepe PE, Martin RR, Ginger VF, Allen MK, et al. Immediate versus delayed fluid resuscitation for hypotensive patients with penetrating torso injuries. N Engl J Med 1994;331:1105-9. [CrossRef]

24. Baykal Y. Book of the Month: Shock and Treatment. In: Baykal Y, Erikci S, Azal O, Karaayvaz M, Zeybek N, Editors. Ankara: GATA Publication House; 2001. p. 101-10. 
DENEYSEL ÇALIŞMA - ÖZET

\section{Sıçanlarda oluşturulan kontrolsüz hemorajik şok modelinde ılık sıvı ile soğuk sıvı resüsitasyonlarının karşılaştırılması}

Dr. Serkan Dilmen, ${ }^{1}$ Dr. Mehmet Eryılmaz, ${ }^{2}$ Dr. Salih Müjdat Balkan, ${ }^{3}$ Dr. Muhittin Serdar, ${ }^{4}$ Dr. Murat Durusu, ${ }^{2}$ Dr. Ali Osman Yıldırım, ${ }^{5}$ Dr. Sanem Aslıhan Dilmen ${ }^{6}$

${ }^{1}$ Gülhane Askeri Tıp Akademisi, Kalp ve Damar Cerrahisi Anabilim Dalı, Ankara

${ }^{2}$ Gülhane Askeri Tıp Akademisi, Acil Tıp Anabilim Dalı, Ankara

${ }^{3}$ Özel TOBB ETÜ Hastanesi, Genel Cerrahi Kliniği, Ankara

${ }^{4}$ Acıbadem Üniversitesi Tıp Fakültesi, Biyokimya Anabilim Dalı, Ankara

${ }^{5}$ Gülhane Askeri Tıp Akademisi Haydarpaşa Asker Hastanesi, Acil Tıp Anabilim Dalı, İstanbul

${ }^{6}$ Ankara Fizik Tedavi ve Rehabilitasyon Eğitim ve Araştırma Hastanesi, Fizik Tedavi ve Rehabilitasyon Kliniği, Ankara

AMAÇ: Bu çalışma, sıçanlarda oluşturulan kontrolsüz hemorajik şok (HŞ) modelinde, soğuk sıvı resüsitasyonunun yaşam süresi, kanama miktarı, kanama hızı, hemodinami, hipotermi, koagülopati, asit-baz dengesi, hematokrit, laktat ve baz defisit üzerine etkilerini, IIk sIVı resüsitasyonunun etkileriyle karşılaştırmak için planlandı.

GEREÇ VE YÖNTEM: Çalışmada ketamin ve ksilazinle anestezi altına alınan 29 sıçanın dalağında, vasküler ve parankim yaralanması ile HŞ modeli oluşturuldu. Hemorajik şokun 30. dakikasında, sıçanlara randomize olarak, $14.5 \mathrm{ml} / \mathrm{kg}$ dozunda $\% 0.9 \mathrm{NaCl}$ solüsyonu, $24^{\circ} \mathrm{C}$ sıcaklıkta (Grup I, n=9) ve $4{ }^{\circ} \mathrm{C}$ sıcaklıkta (Grup 2, n= I0) 20 dakika süreyle intravenöz infüze edildi. Grup I ve 2'nin tedavi etkinliği, sıvı tedavisi uygulanmayan grupla

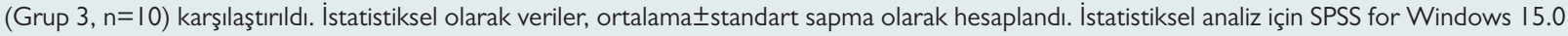
programı, Bonferroni düzeltmeli Mann-Whitney U-testi ve Kaplan-Meier prosedürü kullanıldı. $\mathrm{P} \leq 0.05$ olduğunda, istatistiksel olarak anlamlı kabul edildi.

BULGULAR: Soğuk sıvı resüsitasyonu kanama miktarıı, kanama hızını, asidozu, hipotermiyi, laktatı, baz defisitini artırarak ve de kan basıncını, hematokriti düşürerek yaşam süresini kısaltmıştır.

TARTIŞMA: Travmada sıvı resüsitasyonu ile ilgili olarak; hangi sıvının, hangi sıcaklıkta, hangi miktarda ve ne kadar sürede verileceğini inceleyen birçok deneysel ve klinik çalışmaların planlanmasına büyük ihtiyaç olduğu değerlendirilmiştir.

Anahtar sözcükler: Hemorajik şok; intravenöz soğuk sıvı; sıçan; sıvı resüsitasyonu.

Ulus Travma Acil Cerrahi Derg 2017;23(4):287-293 doi: I0.5505/tjtes.20।6.50487 